International Journal of Child, Youth and Family Studies (2015) 6(2): 204-229

\title{
EARLY LIFE OR EARLY DEATH: SUPPORT FOR CHILD HEALTH LASTS A LIFETIME
}

\section{Stephen Bezruchka}

\begin{abstract}
The first thousand days following conception is a critical period during which a large fraction of adult health is programmed. Societies can structure their support during this period in ways that enhance or damage not only the health and well-being of children, but also the health of the adults they become. Inequality is a major influence on early child health. Nations may focus on trying to effect changes in individual healthrelated behaviors, but public policies promoting more economic equality are more effective in producing health. A national focus on economic growth may produce overstressed parents who have inadequate time and energy for parenting. How a country chooses to allocate its national budget for health and welfare services exposes its priorities. Some of the nations that put the most federal money per person on the first year of life have some of the best overall health; others that focus spending on the later years may have limited health improvements. Economic policies, however, can be overcome in some cases by social and cultural norms, which can override both supportive and unhelpful measures. The path to health looks at its source determinants and supports early life conditions that promote the well-being of children, which in turn will further their health as adults.
\end{abstract}

Keywords: early life, parental leave, epigenetics, economic inequality, determinants of health, adverse childhood experiences

Stephen Bezruchka, MD, MPH, is a Senior Lecturer in the Departments of Global Health and Health Services at the School of Public Health, University of Washington, Box 357230, Seattle, Washington, U.S.A. 98195. Telephone: (206) 932-4928. E-mail: sabez@uw.edu 
International Journal of Child, Youth and Family Studies (2015) 6(2): 204-229

\section{It is easier to build strong children than to repair broken men. \\ Frederick Douglass (1817-1895)}

This article begins by considering factors that produce societal health, and then focuses on evidence that early life is the most critical period for adult health. It concludes by asking: How can we structure the first thousand days after conception to produce health?

Life can be seen as an endeavor where progress is measured by various surrogate markers, with death the ultimate endpoint. Markers of advancement can be income or wealth, using proxies such as one's house, car, vacation site, or the ability to pay off credit card debt. For some, the surrogates might be employment status, colleges that one's children attend, or having a partner get out of jail. In Western societies there is a strong reliance on the importance of individual agency as the means by which the path through life is navigated. In other societies, the focus may be on the support of the extended family, with limited importance of individual efforts. Delaying death is an unstated but highly meaningful indirect goal of this project for most individuals.

People focus on being healthy as individuals. In the teenage years we begin to consider health as a vague concept and rely on myriad sources for guidance. Absent suffering from serious disease in early life, important proxy measures of health in youth are desirable body image, athletic prowess, good coordination, age-appropriate size and weight, and the ability to perform well in school and to navigate social relationships successfully. Factors said to affect these measures may include eating the proper foods, using the right skin and hair products, and exercise regimens. We learn about these approaches through admonitions from parents and friends, and as a result of corporate advertising media that present cleverly packaged messages on how to attain health and beauty. In later years clinical markers such as cholesterol and blood pressure become the surrogate focus for health, requiring new behavioral and medical interventions. Health in older persons becomes focused on treating chronic diseases.

In contrast with this focus on treating or preventing problems of individuals is the concept of population health. A population health approach considers health of a society by monitoring rates of death or diseases in large groups of people, which allows comparisons with groups in other societies. A key measure of population health is life expectancy, a calculation of the average number of years lived by a population if death rates were to remain constant. Infant, child, or adult mortality measures are also used. Monitoring the prevalence of chronic problems such as diabetes, cardiovascular afflictions, or obesity represents a disease focus that leads to treating disease. Death is an easily measured endpoint compared to disease conditions. Monitoring mortality measures in different populations indicates relative health status and can lead to population efforts to avert death that go beyond treating diseases.

Behavioral admonitions (eat right, don't smoke, use a condom) and appropriate medical care are the measures most often recommended to improve health. Pharmaceuticals in particular are seen as ways to prevent a condition (e.g., immunizations), cure a condition (antibiotics for pneumonia), or maintain someone with a risk factor or disease (statins for high cholesterol). In 
International Journal of Child, Youth and Family Studies (2015) 6(2): 204-229

the industrialized countries, the transition from deaths caused by infectious diseases in the young to that of chronic conditions in older ages has led today's pharmaceutical industry to focus on maintenance of people with chronic diseases.

But treating illness is very different from producing health. What do we know about what makes populations healthy? Scientific studies range from anecdotes of individual cases to randomized controlled clinical trials, the so-called gold standard. When comparisons are made among groups in clinical trials, researchers traditionally control for or remove the influence of socioeconomic status from the investigation by various statistical means. This is needed because without factoring out the influence of socioeconomic status, other specific causes can't be identified. Socioeconomic status thus must have a very strong impact on health.

In fact, the socioeconomic gradient in health is ubiquitous. Socioeconomic position is the single most powerful determinant of health and development within every human society on Earth. Stated simply, poorer people have poorer health for almost every outcome considered, because of the choices societies make that privilege or disadvantage strata of people within that society. The importance for health of socioeconomic status has been known for thousands of years, yet even today most people are unlikely to consider relative poverty as a critical risk factor impeding health attainment. How this relationship develops will be the focus of this paper.

\section{Early Life Impacts Health}

The importance of early life - the period from conception through the first two or three years - for adult health has been known since the time of the Greeks and that awareness has been found in Asian and other societies since antiquity. It is little considered in the United States by either the general public or the medical community, even though our growing understanding of the impact of early life adult health is nothing less than a scientific revolution. Memes in the United States today such as "we are all born equal" and "life is what you make of it" make acceptance of this revolution problematic. It defies the American Dream to consider that what happened in your life before you had any consciousness or control over it has critically important effects on your life potential today.

We now have strong evidence that broad environmental conditions that we are exposed to from conception throughout the first few years of life determine to a large degree how we die in later years (Gluckman \& Hanson, 2006; Montez \& Hayward, 2011). The Developmental Origins of Health and Disease (DOHAD) is the new paradigm for understanding the chronic diseases that have replaced infectious conditions as the leading killers in the industrialized countries. DOHAD is a multi-disciplinary field that examines how factors in the environment, broadly considered, during critical periods of development modify the capacity of the organism to cope with later life.

\section{Natural experiments}

Evidence from natural human experiments provides insight into the effects of early life stresses on infant outcomes. The Dutch Hunger Winter was a period of low food availability in 
Holland during World War II, with caloric restrictions from 1,800 calories to less than 1,000 calories occurring between November 1944 and April 1945. Children born of women who were pregnant during this period were followed to adulthood, and the results were striking. Adults who were exposed to the famine in the early months of their gestation were more likely to have mental disorders, neural tube defects, glucose intolerance, an atherogenic lipid profile, altered blood coagulation, female obesity, stress sensitivity, coronary artery disease, and breast cancer. Cognitive function was also affected in later life. Those exposed in mid-gestation had glucose intolerance, as well as kidney and lung problems, while for late gestation exposure the risk of glucose intolerance was greater. These specific findings correlate with the periods when various organs were being formed in the foetus that were impacted by famine conditions.

The many studies from this natural human experiment have demonstrated that nutritional stresses in utero that produce non-optimal growth during the foetal period can have profound health effects later in life (de Rooij, Wouters, Yonker, Painter, \& Roseboom, 2010; Schulz, 2010). Studies also support the intergenerational transmission of health. The progeny of women who were born during the Dutch Hunger Winter have been found to have neonatal adiposity and poor adult health (Painter et al., 2008). The explanation for this finding is not complex: All of us were born of an ovum that was produced by our mother when she was herself developing in her own mother's body. For that reason, our maternal grandmother's condition could have substantial impact on our own health. The health and socioeconomic status of grandparents thus can predict the health of individuals (Schreier \& Chen, 2010).

Nutritional stress during pregnancy and infancy is strongly correlated with many chronic diseases in adulthood, but other kinds of gestational stresses affect us as well. Children born of pregnant women exposed to the psychosocial stress of Hurricane Katrina and 9/11, for example, have been found to have various health issues as they develop (Ohlsson, Shah, et al., 2011). There was an increase in foetal deaths, in preterm births and low birth weight infants for those exposed to Katrina (Currie \& Rossin-Slater, 2013; Zahran et al., 2014). Other elements affecting the foetus are known to affect birth outcomes, including infections such as rubella, drugs such as thalidomide and diethylstilbestrol, environmental factors (e.g., particulate matter in the air), as well as chemical exposures (tobacco smoke).

\section{The foetal origins hypothesis}

A non-experimental way of considering the impact of early life on adult health requires studying subjects as close to the time of conception as possible and following them until death, and then considering the next generation. Ideally, the subjects for such cohort studies would be randomly selected and be in various settings representative of humans around the globe, something currently unthinkable. What follows describes the best studies that consider subjects during their beginnings in utero and for the first few years after birth. Pregnancy outcomes that have been measured include low birth weight, prematurity, and intrauterine growth restriction. In the 1990s David Barker conducted studies of people who were born in the early part of the 20th century in three regions in England where detailed birth records were kept (Hertfordshire, Preston, and Sheffield). He demonstrated an association between low birth weight and coronary heart disease, Type 2 diabetes, and hypertension in adults, findings that became known as the 
International Journal of Child, Youth and Family Studies (2015) 6(2): 204-229

foetal origins hypothesis. Low birth weight is a surrogate marker of impaired foetal growth and development. The results have been replicated for various health conditions in many different populations using other indicators besides birth weight, such as the ponderal index (a birth weight to length ratio) and head circumference that are also proxies of growth and development in utero (Barker, 1998).

Barker later studied infants born at Helsinki’s University Central Hospital between 1923 and 1944, following them to adulthood. Boys with low birth weight who remained small for weight, length, and body mass index during the next two years were more likely to have coronary heart disease and Type 2 Diabetes as adults, even though they had significant catch-up growth after five years of age (Barker, 2012; Barker, Osmond, Kajantie, \& Eriksson, 2009; Eriksson, 2007). Infant growth predicted income 50 years later (Barker, Eriksson, Forsén, \& Osmond, 2005).

Efforts to identify other early life factors affecting later health are ongoing. The British Birth Cohort studies enroll all infants born in one specific week in the United Kingdom and follow them at various ages. The 1958 British Birth Cohort has followed people from birth, and at ages 7, 11, 16, 23, 33, 42, 46, and 50 (Elliott \& Vaitilingam, 2008). A general finding from these extensive data is that having poorer early life situations predisposes to worse health later. Case, Fertig, and Paxson (2005) conclude:

We find, controlling for parental income, education and social class, that children who have experienced poorer uterine environments and poorer health in childhood have significantly lower educational attainment, poorer health and lower socioeconomic status as adults. Moreover, prenatal and childhood health appear to have direct effects on health and economic status in middle age: controlling for educational attainment, and for socioeconomic status and health in earlier adulthood, we find prenatal and childhood health markers are significant predictors of health and economic status at age 42. (pp. 367-368)

How much of adult health is determined in early life? The answer depends on the definition of adult health. One measure is self-rated health, obtained by asking the subject how healthy she or he is on a Likert scale, which patterns actual mortality rates in culturally similar populations. Examination of the 1958 British Birth Cohort members at age 33 found that conditions in early life predicted about half of self-rated health.

In the trajectory from conception to death there are imprinted or latent effects operative in early life that are independent of later events. What has happened in this period cannot later be reversed. Later on, so-called pathway or indirect effects set the person on various life courses that depend on factors such as level of schooling and grade of employment, while cumulative effects, related to dose-response and intensity, consider enhancing and damaging health-related behaviors and environments (Hertzman, 1999). Examples of pathway effects include completing advanced education, while cumulative ones are income earned or damaging drug use. Taken together, the strength of the pathway and cumulative effects are roughly equal to latent effects (Hertzman \& Boyce, 2010). The 1958 British Birth Cohort used age seven as the cutoff for early 
International Journal of Child, Youth and Family Studies (2015) 6(2): 204-229

life, since that is when the second data collection point occurred; other scholarship would put the age lower. Currently there is interest in the first thousand days after conception as the critical period during which adult health is programmed. Roughly half of adult health, the impact of the latent period, is determined early in life. The latent effects are mostly related to socioeconomic status and its consequences.

\section{Psychosocial stress and health}

Stress during pregnancy, characterized by specific negative life events rather than subjective reports, has been linked to inflammatory markers in the women's offspring in their 20s (Entringer et al., 2008). The negative life events considered were: relationship conflicts characterized as divorce, break up, paternity denial, marital infidelity; death of someone close such as a partner, parent, or other child; severe illness of someone close including cancer, heart attack, or stroke; and severe financial problems, such as loss of house by flooding, or sudden unemployment of husband, or foreclosure. Others included a car accident, being unmarried with the child's father not accepted by family, and finally, becoming a political refugee. Cytokine production in response to antigen stimulation, which measures immune function, was assessed in the progeny. Prenatally stressed women showed levels of cytokine production similar to that of chronically stressed women.

Maternal stress may be transmitted to the foetus via: (a) transplacental transport of maternal stress hormones to the foetus; (b) maternal stress-induced release of placental hormones that enter the foetal circulation; and (c) maternal stress-induced effects on placental physiology, including blood flow and changes in foetal metabolism impacting oxygen and glucose usage. These changes may affect organ development and programming of the stress response, as has been found in non-human animal experiments. The same study model was used to demonstrate increased insulin resistance when the study women were in their 20s, as well as decreased memory and other factors known to increase risk for developing diseases in later life (Entringer et al., 2012).

Work is progressing on the biological mechanisms through which prenatal stress affects adult health. One promising approach finds that maternal stress exposure produces shorter telomeres in the resulting young adults, which portends worse health later (Entringer et al., 2011).

Foetal programming and developmental plasticity are terms given to the panoply of processes that mold the foetus to adapt to life outside the uterus. Foetal programming may be the set of adaptive responses that enable successful reproduction, our evolutionary purpose (Gluckman \& Hanson, 2004). In this "Womb with a View" perspective, the foetus scans the environment to prepare for the post-natal one. Epigenetic mechanisms are the likely path for this process. Epigenetic factors on the genome tell the genes to switch on or off, to speak loudly or whisper, and are influenced by a host of broadly considered environmental factors. Most importantly, they are transmitted across generations. Thus transgenerational influences, as well as nutrition, lifestyle, environmental substances, clinical conditions and social stressors, act on the epigenome to produce chronic diseases in later life after successful reproduction (Boekelheide et al., 2012; Hochberg et al., 2011; Lane, Robker, \& Robertson, 2014). 
The placenta, the maternal foetal interface, is actively involved in complex ways in shaping the foetus to survive outside the uterine environment. The placenta provides an immunological barrier between foetus and mother, mediates the transfer of respiratory gases, water, ions, and nutrients, and produces and secretes a vast array of hormones, cytokines, and signaling molecules (Jansson \& Powell, 2007). Placental growth is under the control of imprinted genes (those whose expression depends on their parental origin) that may up- or downregulate growth depending on the parent of origin. Paternally expressed genes tend to enhance foetal growth while maternal ones suppress it. The placenta has a distinct epigenetic profile that changes through gestation in response to the environment. It is involved in foetal brain development and likely impacts child and adult cognitive functioning (Boekelheide et al., 2012; Zeltser \& Leibel, 2011).

There is unequivocal evidence that the first nine months of life before birth are strongly associated with various chronic diseases in adulthood (Paul, 2010). What about the effects after birth on adult health? Biological embedding is one term used to describe postnatal influences on health.

The socioeconomic gradient found in health status appears very early in life. Infant and child disease outcomes are related to the socioeconomic status of the parents: Children of lower socioeconomic status are more likely to be ill and die. Reasons postulated include access to health care, education, material deprivation, psychological and social factors, the physical environment, behaviors, and exposures to pathogens (Colvin et al., 2013). For children admitted to tertiary care hospitals in the U.S., those from lower income zip codes were more likely to die in hospital than those from upper income ones. Children in the U.S. who receive heart transplants and have low socioeconomic status are more likely to have rejection and graft failure (Davies et al., 2013).

What can explain the socioeconomic gradient's effect on health in children? The same stresses linked to complex social, societal, and parental factors that work during pregnancy continue after birth affecting early child development. Growth after birth is an important indicator that portends future health outcomes. For example, weight at one year is inversely proportional to the risk of coronary heart disease in adulthood. Like all population-based measures, however, these data represent risks and averages, not inevitable results. Lower weight at birth or at one year of age does not doom the infant to bad adult outcomes, but the chances of problems are greater. The same concept applies to the rest of the indicators presented here. Similarly, birth weight has been found to be related to cognitive function of grade school children as measured on standardized tests, and is invariant to school quality (Figlio, Guryan, Karbownik, \& Roth, 2014). General statements are presented that do not apply to individuals, but to populations.

Family socioeconomic circumstances during childhood appear to be more important predictors of adult health than later change in income or social mobility. A child who grows up in poverty has worse health in adulthood than a child not growing up in poverty (Chen, Martin, \& Matthews, 2007; Conroy, Sandel, and Zuckerman, 2010). Poverty has adverse effects on brain 
International Journal of Child, Youth and Family Studies (2015) 6(2): 204-229

development (Nelson, 2013). Although in the United States explanations for this inequality often revolve around the lack of access to health services, studies in other countries with universal health care demonstrate the same phenomenon (Seguin et al., 2012).

\section{Attachment theory}

Attachment theory is another important concept in the study of early life outcomes. John Bowlby, a British psychiatrist, studied separation in children before, during and after the Second World War and developed a theory of attachment as an evolutionary adaptation to facilitate socialization. Comfort with interpersonal closeness and a willingness to depend on others have species survival benefits.

Bowlby's work with Mary Ainsworth led to categorization of attachment styles (Bowlby, 1988). Secure attachment resulted from supportive contact from a caregiver in early life.

Securely attached infants bond with the primary caregiver, tend to be more comfortable around strangers, and cope with stress knowing they can retreat to a secure base. Humans are almost the only primate with white sclerae (whites in their eyes). Eye contact is an important process for secure attachment to occur and the eyes of a single caregiver are important for this process. A major goal of infancy can be seen as the creation of a secure attachment bond with a primary caregiver and the development of self-regulation as the infant interacts with its environment. The infant is exposed to and processes enhancing touch, sounds, and images. This works better in a socially rich environment (Schore, 2005).

If an infant is presented with many different pairs of eyes early on, he or she is more likely to be uncomfortable among strangers and exhibit avoidance or ambivalence towards caregivers. Attachment styles are termed secure or insecure with three types termed: dismissing, preoccupied, and fearful. Another categorization of insecure attachment is anxious, avoidant, and disorganized. About half the adults in people in the U.S. and England may have a secure attachment style (Ciechanowski et al., 2004; Stansfeld, Head, Bartley, \& Fonagy, 2008).

Adults with predominantly secure attachment style are believed to have experienced consistently responsive early care giving and are generally comfortable depending on and being readily comforted by others. Adults with predominantly dismissing attachment style are posited to have experienced early care giving that was consistently emotionally unresponsive and from an early age they develop strategies in which they are highly selfreliant and uncomfortable trusting others. On the other hand, adults with predominantly preoccupied attachment style experienced inconsistently responsive care giving; to ensure proximity to caregivers, they learned to do more than their share in attachment relationships. They are generally emotionally dependent on others' approval and generally have poor self-esteem. People with a predominantly fearful attachment style also may desire social contact, but this desire is inhibited by fear of rejection. They are hypothesized to have had overly critical or harshly rejecting care giving and as adults are more likely to demonstrate approach-avoidance behavior interpersonally, stemming from a fear of intimacy. (Ciechanowski et al., 2004, p. 721) 
International Journal of Child, Youth and Family Studies (2015) 6(2): 204-229

Attachment is related to social position, context, culture, and economic circumstances in a complicated way with much research being done. Healthy early life attachment may facilitate resilience to adversity encountered then and promote better later health (Bartley, Head, \& Stansfeld, 2007; Chida \& Steptoe, 2008; Stansfeld, Head, et al., 2008; Stansfeld, Clark, Rodgers, Caldwell, \& Power, 2008). Mortality has been found to be higher in diabetics among those without secure attachment (Ciechanowski et al., 2010). Avoidant and anxious adult attachment styles are related to worse health outcomes (McWilliams \& Bailey, 2010). There are stress and immune function consequences (Jaremka et al., 2013).

Neurocognitive development imaging shows that the visual cortex of the brain is very active and is being remodeled in the first six months of life, followed by the auditory cortex which peaks in the next few years. Children raised in a rich sound environment where complex language is used by caregivers develop better than those in situations with limited words and phrases. Such environments correlate with socioeconomic status: Wealthier families tend to expose children to richer verbal discussions, while poorer ones may focus on words of admonishment (Hart \& Risley, 1995). Pre-literacy skills are more advanced in higher SES children and enable them to do better at school. Pediatricians now recommend that parents read to children right from birth as a means of fostering attachment and exposure to a varied vocabulary. As a child grows, the frontal lobes of the brain, our social organ, develop. While in the first year the infant may do best with a single caregiver, the presence of a second caregiver in the second year is important and beyond that period a nourishing social environment enhances social adaptation. Stimulating surroundings with other children are important after the first two years of life.

During the 1980s when abortion and contraception were forbidden in Romania, that country had high birth rates with many abandoned infants and children. Large numbers of orphans were placed into very deprived environments within their first month of life as the country focused on repaying foreign debt. These infants spent most of their days unattended. Studies of their adoptions abroad show that the more severe deprivation they were exposed to, the more severe attachment, cognitive, and behavioral problems they have. The difficulties orphans experienced, including severe cognitive and behavioral problems, do not return to normal levels even after placement in a nurturing environment. Brain imaging studies show significant damage due to this early life effect (Marshall, 2014; Nelson, Fox, \& Zeanah, 2014).

An ideal study of the first few years of life after birth for lifelong health impacts would require simultaneous cohort studies that enrolled a substantial sample of people in many societies, and followed their progeny from conception to death. The perfect study would require wearing a lifelong personal camera to monitor behaviors such as breastfeeding, parenting, social interactions, and other activities. Although this kind of research obviously has not been done, a number of existing cohort studies have been conducted that provide useful information.

The 1958 British Birth Cohort study described earlier found that the latent factors of early life at age seven that mattered most for later health were whether the child was read to on a regular basis by his or her parents, whether the child adjusted easily when first attending school, and what proportion of ultimate adult height the child reached at age 7 (Hertzman, Power, 
International Journal of Child, Youth and Family Studies (2015) 6(2): 204-229

Matthews, \& Manor, 2001). These findings are consistent with healthy physical development and attachment.

Studies with a Kaiser patient population in San Diego, California in the 1980s revealed that abuse in early life was common and related to adult health problems. Abuse explained many compensatory adult behaviors such as smoking, overeating, alcohol and drug use, which provide immediate partial relief from the emotional problems suffered earlier. Adverse childhood experiences (ACEs) were categorized as: abuse (emotional, physical and sexual); household dysfunction (violence towards mother, not being raised by biologic parents, household member being alcoholic or drug user, household member with significant mental problems); and neglect, either physical or emotional. The more of these ACEs a person experiences, the higher the chance of dying younger, the greater the number of antipsychotic prescriptions consumed, and the greater the likelihood of teen pregnancy or paternity, injection drug use, or attempted suicide in later life (Felitti, 2009; Felitti \& Anda, 2010; Felitti et al., 1998; Maté, 2008). The biological mechanisms that produce the adverse effects of ACEs are likely epigenetic changes in the expression of the genome (Essex et al., 2013). Knowing the possible biology that may operate behind an assertion considerably strengthens it.

What has been presented here is the effect of early childhood stress on health across the lifespan. Stress in childhood can be positive, the normal kind that challenges us to develop. It can be tolerable but relatively short-lived, such as a natural disaster or family disruption, and may benefit the child developmentally if there is adequate support. Toxic stress, however, results from sustained adverse experiences that children find difficult to manage. Toxic stress adversely affects brain development, and models link stress in early childhood to chronic diseases of aging (Middlebrooks \& Audage, 2008; Miller, Chen, \& Parker, 2011; Pesonen \& Raikkonen, 2012).

\section{Parenting and health}

Good parenting is beneficial for the health of offspring. Some people can overcome the impact of having bad parenting and adversity, but it is better not to have this challenge (Gladwell, 2008). Defining what represents good parenting is problematic, but animal experiments shed some light on the subject.

The brain is linked to the body's stress response via neuronal mechanisms, the autonomic nervous system (ANS), as well as hormonally by the hypothalamic-pituitary-adrenal (HPA) axis that modulates the stress response. There is considerable evidence that animals lower down in the social hierarchy have different stress mechanisms than those higher up. Cortisol, secreted by the adrenal gland, is our chronic stress hormone. In rat experiments, removal from the mother for even a short period of time in the rat pup's life can permanently alter the HPA stress response. There is a brief window when extra licking and grooming after return to the mother can result in a more adaptive stress response. The others not given this extra parenting showed more rapid aging (Hertzman \& Boyce, 2010).

Rat pups that were more frequently or less frequently groomed by their mothers have HPA axis differences related to epigenetic changes in the expression of DNA. Less licking and 
grooming resulted in a more highly reactive HPA axis. These behaviors are biologically embedded and passed on to the next generation. Rat pups that have been highly licked and groomed will, upon reaching adulthood, lick and groom their pups more, while those exposed to less licking and grooming will do likewise with their pups. Cross-fostering studies demonstrate that the licking and grooming behavior is patterned by the exposure rather than genetically, indicating transfer by epigenetic means (Hertzman \& Boyce, 2010). Similar neural mechanisms are found in humans as well, and explain poorer outcomes found in Romanian orphans (Rilling \& Young, 2014). Many studies of the impact of parenting and social relations on health come from extreme conditions as in Romania presented above.

Having both parents in the home can affect the level of positive parenting that is available to a child. Parents who find raising children a challenge today will mostly agree that it is easier when two people work together. A study was done in Sweden on the effect of having only one parent in the home on child mortality from age one to 16 . The mortality impact of being in a single-parent household for boys was 50\% greater than for two-parent boys, and for girls $21 \%$ greater (Weitoft, Hjern, Haglund, \& Rosén, 2003). Studies looking at non-mortality measures suggest children in single-parent households have worse health (Bramlett and Blumberg, 2007; Tobias, Kokaua, Gerritsen, \& Templeton, 2010; Troxel \& Matthews, 2004).

A child's parenting that is sub-optimal can predict more ill-health during mid-childhood (Waylen, Stallard, \& Stewart-Brown, 2008). For example, a child exposed to intimate partner violence is more likely to have asthma, although the ability of the mother to maintain positive caregiving may buffer that risk (Suglia, Enlow, Kullowatz, \& Wright, 2009). A study looking at hypertension among adult black men in the U.S. found considerably higher levels among those who did not live with both parents when growing up (Barrington, Adeyemo, \& Rotimi, 2014).

Many parenting studies examine children with severe disabilities because they are easier to study. Such families have considerable stress. Training and support for these families seems to have a beneficial effect (Dykens, Fisher, Taylor, Lambert, \& Miodrag, 2014). Studies usually control for socioeconomic status and so do not study those differences. With very high levels of parental stress, the interventions studied don't work as well (Osborne, McHugh, Saunders, \& Reed, 2008). Parental warmth, however, can buffer childhood abuse's impact on adult health (Carroll et al., 2013).

What about non-parental care in early childhood? During brain development after the age of two, the frontal lobes undergo rapid remodeling. A stimulating social environment, such as play with other children, is necessary for this remodeling. Thus social relationships are vital to brain development and therefore to producing health. In a similar manner, the impact of friendship and support on averting mortality is greater than practicing individual health-related behaviors (Holt-Lunstad, Smith, \& Layton, 2010). High social support from any source helps alleviate early childhood adversity (Runsten et al., 2014).

Studies are mixed on the extent to which non-parental child care benefits children, with variation depending on the study and outcome measures employed as well as the socioeconomic status of the families involved (Lee, 2014). High-quality care is associated with improved 
International Journal of Child, Youth and Family Studies (2015) 6(2): 204-229

children's language development, cognitive skills, and behavioral adjustment. Age of the child when care begins as well as the amount of time spent in non-parental care also affects outcomes. The nature of the home environment, whether it is harsh, disciplinary, supportive, or responsive, and whether parents have significant mental illness or other risk factors, also matters. Is the childcare center-based and typically then state-regulated? Such care may be called nursery school, or pre-school, and may be associated with a workplace and accredited by a national organization. Family childcare or the use of nannies represent other arrangements. Whatever the source, more stable childcare situations result in greater cognitive test score improvement.

With the increasing levels of employment outside the home for women and thus the increase in non-parental care, what matters for the child's well-being ranges from pre-existing risk factors to the quality of the care and how it is financially supported. Many governments are moving to institute universal access to non-parental child care (Jenkins, 2014). Providing the nurturing early life that impacts adult health will be an increasing challenge around the world as today's globalization changes the work world. For families in poverty, the mitigating effects of quality non-parental child care on adult outcomes may be significant (Lee, 2005, 2014; Leseman, 2013; Love et al., 2003; Quan, Bureau, Yurkowski, Moss, \& Pallanca, 2013).

\section{Socioeconomic disadvantage in early life}

In countries such as the United States, with its emphasis on individualism, the pursuit of happiness and achievement is made more difficult by vast economic inequality. Parenting by those lower down the socioeconomic ladder is more problematic for many measures including educational outcomes (Reeves \& Howard, 2013). Richer parents have more opportunities for raising healthy children. Parents in the U.S.A. facing economic hardship are more likely to be single and focus on survival and "natural growth" of their children while richer parents focus on the "concerted cultivation of children" (Lareau, 2011). International comparisons of parenting demonstrate considerable variations (Druckerman, 2012). Like other concepts discussed here, poorer parents, individually, are not necessarily worse parents than richer ones, but opportunities for better parenting occur higher up the economic hierarchy.

Many studies demonstrate that poverty in early life is the greatest obstacle to a healthy adulthood. A New Zealand study looked at children followed to age 26 and found a strong impact of early life socioeconomic circumstances on adult health. The higher up the economic ladder the family was during childhood, the healthier the adult (Poulton et al., 2002). This study has been replicated in many different societies for many different measures of adult health (Braveman \& Barclay, 2009). While social support may buffer the adverse effects of relative poverty in early life, it can't do away with them (Andersen \& Mortensen, 2006; Kuh, Hardy, Langenberg, Richards, \& Wadsworth, 2002; Luo, Wilkins, \& Kramer, 2006).

\section{Political Economy Approaches to Better Health}

Political economy studies the role of the state in the economic and social organization of a country by asking what public policies and institutions bring people closer to an ideal society. The distribution of wealth and income is central to a political economy approach. We use this 
International Journal of Child, Youth and Family Studies (2015) 6(2): 204-229

strategy in discussing how to improve population health. Mortality trajectories in relation to economic growth typically demonstrate what is called a business procyclical quality, namely that health improves more during economic declines than during booms, at least in developed nations (Bezruchka, 2009). The benefits of economic growth on societal outcomes in rich nations today have reached a plateau, and there is little evidence of a human development advantage from expanding the economy, as compared to making it more equitable (Wilkinson \& Pickett, 2010).

Economic inequality today is at a record high, reaching levels of the gilded age and the period before the Great Depression. The compression of inequality that followed reached its nadir in the 1970s. Today's inequality will likely swell even more (Piketty, 2014) and be responsible for increasing health inequities (Wilkinson \& Pickett, 2010). It may be time to reconsider current models of political economy for their effects on health.

Mortality outcomes very greatly among rich nations with a paradox: The richest nation, the United States, has perhaps the worst health outcomes. This includes nearly all mortality indicators and many other measures of well-being (UNICEF Office of Research - Innocenti, 2013). There is no substantial group within the U.S. that can claim stellar health outcomes, if the standard of comparison is similar groups in other rich nations (National Research Council \& Institute of Medicine, 2013). Reasons for this phenomenon go beyond the lack of universal health care and probably relate to historical issues and American exceptionalism, along with that country's extreme inequality (Bezruchka, 2012a, 2012b). One death in three in the U.S. can be linked to its income inequality (Kondo et al., 2009); the U.S. is a convincing example that the wealthiest societies are not necessarily the healthiest.

From a political economy perspective it is preferable to create conditions for healthy early life outcomes that depend less on individual agency in order to increase the chances that more people will be healthier as they age. We begin considering individual steps.

\section{Individual health advice}

Since socioeconomic status is critical for good health outcomes, one admonition directed at the individual family who desires to have a healthy child is to not be poor, or at least to not be poor during their children's early life. The efficacy of this advice depends on the society in which the future parents live. The United States, for example, has the highest child poverty rates of all rich nations, so having a family there may be inadvisable unless one is quite well off (UNICEF Office of Research - Innocenti, 2013). Even then, health outcomes for those privileged in the U.S. are not as favorable as similar people in other rich nations (National Research Council \& Institute of Medicine, 2013). Inequality in a society affects everyone to a degree, rich and poor families alike.

Interventions that address individual behaviors to improve child health outcomes are well-intentioned but typically not that effective. Dietary prescriptions, for example, are fraught with hazard. Pregnant women are given nutritional advice in a clinical setting and through the media. Although variations in the maternal nutrient balance of carbohydrates, fats, and proteins affect foetal growth, there is no consensus for population level, well-researched, maternal dietary 
International Journal of Child, Youth and Family Studies (2015) 6(2): 204-229

guidelines beyond suggesting an optimal healthy balanced diet (Wood-Bradley, Henry, Vrselja, Newman, \& Armitage, 2013). Often women do not recognize they are pregnant until towards the end of the first trimester when many exposures that adversely affect the foetus may already have taken place. Because a girl is a potential mother from the time of her own conception, the girl's life history matters more for her child's health than what she does during pregnancy.

Prenatal or antenatal care, the impact of visiting a clinic while pregnant, is thought to be of great benefit for the progeny. However, demonstrating an independent effect of prenatal care for populations is difficult in rich and poor nations alike (Kramer et al., 2001). Health outcomes are heavily determined by what happened to the mother before she became pregnant. Such statements are not meant to suggest that pregnant women avoid prenatal care, but for most women without pregnancy complications the benefits of prenatal care as generally practiced are limited in scope (Di Mario, Basevi, Gori, \& Spettoli, 2005). Recognizing the limitations of dealing with individuals, the political economy perspective would structure society for ensuring the best infant, child, and adult health outcomes. Political choices to be considered include the following.

\section{Aim for societies with little poverty}

If low socioeconomic status is the pre-eminent condition impacting health, then perhaps poverty should be considered a disease or at least a risk factor to be treated with income (Bloch et al., 2008; Bloch, Rozmovits, and Giambrone, 2011; Costello, Erkanli, Copeland, \& Angold, 2010). Treating the disease of poverty with income or some kind of financial support is a political economy "medicine”. Rich countries have remarkably different levels of support for various peoples within their nations. Some, like the U.S., have low government expenditures on what is termed social welfare, namely financial help for the less advantaged (Bradley, Elkins, Herrin, \& Elbel, 2011; Piketty, 2014). By contrast, the Scandinavian countries are known for their non-means tested welfare supports (Booth, 2014). Societies could provide a basic income guarantee.

This intervention was proposed by a Republican President in the United States in 1969 and came close to becoming law (Burke \& Burke, 1974). The Swedish government prioritizes spending directed at the first year of life. This is consistent with overwhelming evidence that spending directed at early life averts spending for disease conditions in later life. Sweden tries to assist parents in parenting during the early years (Campbell et al., 2014; Organisation For Economic Co-Operation and Development [OECD], 2007; Raphael, 2010a, 2010b).

\section{Provide financial support for periods of pregnancy and parenting}

Given the difficulties of being pregnant and of parenting, a political economy strategy would make this period as easy as possible for families. One way is to provide paid leave for pregnant women working outside the home, and for parents once the child is born. Almost all rich nations except the United States have a paid antenatal leave policy varying in length up to four months. Only two nations globally do not have a federally mandated paid parental leave policy (paid maternal postnatal leave, at a minimum), the United States and Papua New Guinea 
International Journal of Child, Youth and Family Studies (2015) 6(2): 204-229

(Addati, Cassirer, \& Gilchrist, 2014). There is considerable evidence that parental leave results in substantially improved outcomes (Cerón-Mireles, Harlow, \& Sánchez-Carrillo, 1996; Guendelman et al., 2009; Heymann \& McNeill, 2013; Tanaka, 2005; Wüst, 2014).

\section{Make parenting support widely available}

Evidence-based home visiting programs can improve parenting, whereas programs like pre-kindergarten education outsources parenting. The U.S. focus is primarily on funding pre-k education rather than improving parenting (Reeves \& Howard, 2013). In the last five years (2009 to 2013), the U.S. federal government has allocated \$37.5 billion to Head Start, 25 times the \$1.5 billion that it has allocated to evidence-based home visiting programs. Yet nurse home visitation programs (Nurse Family Partnerships) for vulnerable families have been found to improve health outcomes. These benefits extend not only to behavioral outcomes but also to mortality. In a country where parents are seen as private agents and solely in charge of their family's destiny, attempting to craft policies to provide this kind of social "medicine” is challenging (Eckenrode et al., 2010; Kitzman et al., 2010; Olds et al., 2010).

High-quality, comprehensive, intensive interventions that stimulate the early childhood environment have been found to not only improve cognitive skills, but also substantially boost adult health. Efforts directed from birth through age five produced significantly better outcomes than those directed beyond school entry. A study carried out in North Carolina, for example, used gold standard techniques of investigation to demonstrate these findings (Campbell et al., 2014). Involving communities in the process can improve child health.

The Early Development Instrument (EDI) was developed in Canada as a tool for measuring population health in early life. The EDI is carried out by a teacher in kindergarten to assess a child's school readiness in five domains of child development: physical health and wellbeing, social competence, emotional maturity, language and cognitive development, and communication skills and general knowledge. Neighborhood comparisons are made so the community has a sense of their children's readiness to learn (Hertzman \& Bertrand, 2007). When communities are aware of the importance of early life on adult outcomes, they can act to improve those circumstances. The EDI has also been widely implemented in Australia (Janus et al., 2007).

In summary, early life conditions have dramatic effects on adult health. The avenues for improving early life conditions include working with individual families or creating societal conditions in which salutary effects occur naturally. If the premise is accepted that social and economic inequality is at the root of most undesirable outcomes, then the task at hand is to work at the societal level to reduce inequality and direct resources towards producing a healthy early life. The way to deal with social problems is with social forces. Socioeconomic status lies at the root of most health issues, so limiting inequalities in society is the key political issue that must be addressed. From a political economy perspective, utopian interventions such as a progressive transparent global wealth tax, an income tax, and an inheritance tax could bring about the revenue required to support early life (Piketty, 2014). Evidence of benefit may be seen in shortterm surrogate outcomes, but the major impacts on mortality will take generations for full effect. 
International Journal of Child, Youth and Family Studies (2015) 6(2): 204-229

An important early step in this process will be to create awareness of the critical role of early life conditions in the development of health and disease, with a focus on the links to economic inequality. The public everywhere needs to understand this critically important information and recognize that individuals aren't to blame. Our task is to accurately present the facts of early life in a way that raises awareness and leads to dialogue and change. People everywhere need to be involved in discussions of how early life affects all of us.

Like most scientific revolutions, that task is formidable. Phenomenal increases in communication avenues for reaching large numbers of people suggest that the way forward is possible. We must begin. 
International Journal of Child, Youth and Family Studies (2015) 6(2): 204-229

\section{References}

Addati, L., Cassirer, N., \& Gilchrist, K. (2014). Maternity and paternity at work: Law and practice across the world. Geneva: International Labour Office.

Andersen, A.-M. N., \& Mortensen, L. H. (2006). Socioeconomic inequality in birth outcomes: What do the indicators tell us, and where do we find the data? Canadian Medical Association Journal, 174(10), 1429-1430. http://dx.doi.org/10.1503/cmaj.060349

Barker, D. J. P. (1998). Mothers, babies, and health in later life. Edinburgh: Churchill Livingstone.

Barker, D. J. P. (2012). Developmental origins of chronic disease. Public Health, 126(3), 185189. http://dx.doi.org/10.1016/j.puhe.2011.11.014

Barker, D. J. P., Eriksson, J. G., Forsén, T., \& Osmond, C. (2005). Infant growth and income 50 years later. Archives of Disease in Childhood, 90(3), 272-273. http://dx.doi.org/10.1136/adc.2003.033464

Barker, D. J. P., Osmond, C., Kajantie, E., \& Eriksson, J. G. (2009). Growth and chronic disease: findings in the Helsinki Birth Cohort. Annals of Human Biology, 36(5), 445-458. http://dx.doi.org/10.1080/03014460902980295

Barrington, D. S., Adeyemo, A. A., \& Rotimi, C. N. (2014). Childhood family living arrangements and blood pressure in black men: The Howard University Family Study. Hypertension, 63(1), 48-53. http://dx.doi.org/10.1161/hypertensionaha.113.01629

Bartley, M., Head, J., \& Stansfeld, S. (2007). Is attachment style a source of resilience against health inequalities at work? Social Science and Medicine, 64(4), 765-775. http://dx.doi.org/10.1016/j.socscimed.2006.09.033

Bezruchka, S. (2009). The effect of economic recession on population health. Canadian Medical Association Journal, 181(5), 281-285. http://dx.doi.org/10.1503/cmaj.090553

Bezruchka, S. (2012a). American experiences. In D. Raphael (Ed.), Tackling health inequalities: Lessons from international experiences (pp. 33-62). Toronto: Canadian Scholars’ Press.

Bezruchka, S. (2012b). The hurrider I go the behinder I get: The deteriorating international ranking of U.S. health status. Annual Review of Public Health, 33(1), 157-173. http://dx.doi.org/10.1146/annurev-publhealth-031811-124649

Bloch, G., Etches, V., Gardner, C., Pellizzari, R., Rachlis, M., Scott, F., \& Tamari, I. (2008). Poverty reduction: policy options and perspectives. Ontario Medical Review, 75(6), 4248.

Bloch, G., Rozmovits, L., \& Giambrone, B. (2011). Barriers to primary care responsiveness to poverty as a risk factor for health. BMC Family Practice, 12(1), 62. http://dx.doi.org/10.1186/1471-2296-12-62 
International Journal of Child, Youth and Family Studies (2015) 6(2): 204-229

Boekelheide, K., Blumberg, B., Chapin, R. E., Cote, I., Graziano, J. H., Janesick, A., ... Rogers, J. (2012). Predicting later-life outcomes of early-life exposures. Environmental Health Perspectives, 120(10), 1353-1361. http://dx.doi.org/10.1289/ehp.1204934

Booth, M. (2014). The almost nearly perfect people: The truth about the Nordic miracle. London: Jonathan Cape.

Bowlby, J. (1988). Developmental psychiatry comes of age. The American Journal of Psychiatry, 145(1), 1-10. http://dx.doi.org/10.1176/ajp.145.1.1

Bradley, E. H., Elkins, B. R., Herrin, J., \& Elbel, B. (2011). Health and social services expenditures: associations with health outcomes. BMJ Quality and Safety, 20(10), 826831. http://dx.doi.org/10.1136/bmjqs.2010.048363

Bramlett, M. D., \& Blumberg, S. J. (2007). Family structure and children's physical and mental health. Health Affairs (Millwood), 26(2), 549-558. http://dx.doi.org/10.1377/hlthaff.26.2.549

Braveman, P., \& Barclay, C. (2009). Health disparities beginning in childhood: A life-course perspective. Pediatrics, 124(Supplement 3), S163-S175. http://dx.doi.org/10.1542/peds.2009-1100d

Burke, V. J., \& Burke, V. (1974). Nixon's good deed: Welfare reform. New York: Columbia University Press.

Campbell, F., Conti, G., Heckman, J. J., Moon, S. H., Pinto, R., Pungello, E., \& Pan, Y. (2014). Early childhood investments substantially boost adult health. Science, 343(6178), 14781485. http://dx.doi.org/10.1126/science. 1248429

Carroll, J. E., Gruenewald, T. L., Taylor, S. E., Janicki-Deverts, D., Matthews, K. A., \& Seeman, T. E. (2013). Childhood abuse, parental warmth, and adult multisystem biological risk in the Coronary Artery Risk Development in Young Adults study. Proceedings of the National Academy of Sciences, 110(42), 17149-17153. http://dx.doi.org/10.1073/pnas.1315458110

Case, A., Fertig, A., \& Paxson, C. (2005). The lasting impact of childhood health and circumstance. Journal of Health Economics, 24(2), 365-389. http://dx.doi.org/10.1016/j.jhealeco.2004.09.008

Cerón-Mireles, P., Harlow, S. D., \& Sánchez-Carrillo, C. I. (1996). The risk of prematurity and small-for-gestational-age birth in Mexico City: the effects of working conditions and antenatal leave. American Journal of Public Health, 86(6), 825-831. http://dx.doi.org/10.2105/ajph.86.6.825

Chen, E., Martin, A. D., \& Matthews, K. A. (2007). Trajectories of socioeconomic status across children's lifetime predict health. Pediatrics, 120(2), E297-E303. http://dx.doi.org/10.1542/peds.2006-3098

Chida, Y. C., \& Steptoe, A. (2008). Positive psychological well-being and mortality: A quantitative review of prospective observational studies. Psychosomatic Medicine, 70(7), 741-756. http://dx.doi.org/10.1097/psy.0b013e31818105ba 
International Journal of Child, Youth and Family Studies (2015) 6(2): 204-229

Ciechanowski, P., Russo, J., Katon, W., Von Korff, M., Ludman, E., Lin, E., Simon, F. \& Bush, T. (2004). Influence of patient attachment style on self-care and outcomes in diabetes. Psychosomatic Medicine, 66(5), 720-728. http://dx.doi.org/10.1097/01.psy.0000138125.59122.23

Ciechanowski, P., Russo, J., Katon, W. J., Lin, E. H. B., Ludman, E., Heckbert, S., ... Young, B. (2010). Relationship styles and mortality in patients with diabetes. Diabetes Care, 33(3), 539-534. http://dx.doi.org/10.2337/dc09-1298

Colvin, J. D., Zaniletti, I., Fieldston, E. S., Gottlieb, L. M., Raphael, J. L., Hall, M., . .. Shah, S. (2013). Socioeconomic status and in-hospital pediatric mortality. Pediatrics, 131(1), e182-e190. http://dx.doi.org/10.1542/peds.2012-1215

Conroy, K., Sandel, M., \& Zuckerman, B. (2010). Poverty grown up: How childhood socioeconomic status impacts adult health. Journal of Developmental and Behavioral Pediatrics, 31(2), 154-160. http://dx.doi.org/10.1097/dbp.0b013e3181c21a1b

Costello, E. J., Erkanli, A., Copeland, W., \& Angold, A. (2010). Association of family income supplements in adolescence with development of psychiatric and substance use disorders in adulthood among an American Indian population. Journal of the American Medical Association, 303(19), 1954-1960. http://dx.doi.org/10.1001/jama.2010.621

Currie, J., \& Rossin-Slater, M. (2013). Weathering the storm: Hurricanes and birth outcomes. Journal of Health Economics, 32(3), 487-503. http://dx.doi.org/10.1016/j.jhealeco.2013.01.004

Davies, R. R., Russo, M. J., Reinhartz, O., Maeda, K., Rosenthal, D. N., Chin, C., Bernstein, D., \& Mallidi, H. R. (2013). Lower socioeconomic status is associated with worse outcomes after both listing and transplanting children with heart failure. Pediatric Transplantation, 17(6), 573-581. http://dx.doi.org/10.1111/petr.12117

de Rooij, S. R., Wouters, H., Yonker, J. E., Painter, R. C., \& Roseboom, T. J. (2010). Prenatal undernutrition and cognitive function in late adulthood. Proceedings of the National Academy of Sciences, 107(39), 16881-16886. http://dx.doi.org/10.1073/pnas.1009459107

Di Mario, S., Basevi, V., Gori, G., \& Spettoli, D. (2005). What is the effectiveness of antenatal care? Copenhagen: WHO Regional Office for Europe (Health Evidence Network report).

Druckerman, P. (2012). Bringing up bébé: One American mother discovers the wisdom of French parenting. New York: Penguin Press.

Dykens, E. M., Fisher, M. H., Taylor, J. L., Lambert, W., \& Miodrag, N. (2014). Reducing distress in mothers of children with autism and other disabilities: A randomized trial. Pediatrics, 134(2), e454-e463. doi: 10.1542/peds.2013-3164 http://dx.doi.org/10.1542/peds.2013-3164 
International Journal of Child, Youth and Family Studies (2015) 6(2): 204-229

Eckenrode, J., Campa, M., Luckey, D. W., Henderson, C. R., Cole, R., Kitzman, H., ... Olds, D. (2010). Long-term effects of prenatal and infancy nurse home visitation on the life course of youths 19-year follow-up of a randomized trial. Archives of Pediatrics and Adolescent Medicine, 164(1), 9-15. http://dx.doi.org/10.1001/archpediatrics.2009.240

Elliott, J., \& Vaitilingam, R. (2008). Now we are 50: Key findings from the national child development study. London: Centre for Longitudinal Studies.

Entringer, S., Buss, C., Swanson, J. M., Cooper, D. M., Wing, D. A., Waffarn, F., \& Wadhwa, P. D. (2012). Fetal programming of body composition, obesity, and metabolic function: The role of intrauterine stress and stress biology. Journal of Nutrition and Metabolism, 2012, 16. doi: $10.1155 / 2012 / 632548$

Entringer, S., Epel, E. S., Kumsta, R., Lin, J., Hellhammer, D. H., Blackburn, E. H., Wüst, S., \& Wadhwa, P. D. (2011). Stress exposure in intrauterine life is associated with shorter telomere length in young adulthood. Proceedings of the National Academy of Sciences, 108(33), E513-E518. http://dx.doi.org/10.1073/pnas.1107759108

Entringer, S., Kumsta, R., Nelson, E. L., Hellhammer, D. H., Wadhwa, P. D., \& Wust, S. (2008). Influence of prenatal psychosocial stress on cytokine production in adult women. Developmental Psychobiology, 50(6), 579-587. http://dx.doi.org/10.1002/dev.20316

Eriksson, J. G. (2007). Epidemiology, genes and the environment: lessons learned from the Helsinki Birth Cohort Study. Journal of Internal Medicine, 261(5), 418-425. http://dx.doi.org/10.1111/j.1365-2796.2007.01798.x

Essex, M. J., Boyce, T. W., Hertzman, C., Lam, L. L., Armstrong, J. M., Neumann, S. M. A., \& Kobor, M. S. (2013). Epigenetic vestiges of early developmental adversity: Childhood stress exposure and DNA Methylation in adolescence. Child Development, 84(1), 58-75. http://dx.doi.org/10.1111/j.1467-8624.2011.01641.x

Felitti, V. J. (2009). Adverse childhood experiences and adult health. Academic Pediatrics, 9(3), 131-132. http://dx.doi.org/10.1016/j.acap.2009.03.001

Felitti, V. J., \& Anda, R. F. (2010). The relationship of adverse childhood experiences to adult medical disease, psychiatric disorders and sexual behavior: Implications for healthcare. In R. A. Lanius, E. Vermetten, \& C. Pain (Eds.), The impact of early life trauma on health and disease: The hidden epidemic (pp. 77-87). Cambridge: Cambridge University Press. http://dx.doi.org/10.1017/cbo9780511777042.010

Felitti, V. J., Anda, R. F., Nordenberg, D., Williamson, D. F., Spitz, A. M., Edwards, V., Koss, M.P., \& Marks, J. S. (1998). Relationship of childhood abuse and household dysfunction to many of the leading causes of death in adults. The Adverse Childhood Experiences (ACE) Study. American Journal of Preventive Medicine, 14(4), 245-258.

http://dx.doi.org/10.1016/s0749-3797(98)00017-8 
International Journal of Child, Youth and Family Studies (2015) 6(2): 204-229

Figlio, D., Guryan, J., Karbownik, K., \& Roth, J. (2014). The effects of poor neonatal health on children’s cognitive development. American Economic Review, 104(12), 3921-3955. http://dx.doi.org/10.1257/aer.104.12.3921

Gladwell, M. (2008). Outliers:The story of success. New York: Little, Brown and Company.

Gluckman, P. D., \& Hanson, M. A. (2004). Living with the past: evolution, development, and patterns of disease. Science, 305(5691), 1733-1736. http://dx.doi.org/10.1126/science.1095292

Gluckman, P. D., \& Hanson, M. A. (Eds.). (2006). Developmental origins of health and disease. Cambridge: Cambridge University Press. http://dx.doi.org/10.1017/CBO9780511544699

Guendelman, S., Hubbard, A., Hosang, N., Pearl, M., Graham, S., \& Kharrazi, M. (2009). Maternity leave in the ninth month of pregnancy and birth outcomes among working women. Women's Health Issues, 19(1), 30-37. http://dx.doi.org/10.1016/j.whi.2008.07.007

Hart, B., \& Risley, T. R. (1995). Meaningful differences in the everyday experience of young American children. Baltimore: P.H. Brookes.

Hertzman, C. (1999). The biological embedding of early experience and its effects on health in adulthood. Annual of the New York Academy of Sciences, 896(1), 85-95. http://dx.doi.org/10.1111/j.1749-6632.1999.tb08107.x

Hertzman, C., \& Bertrand, J. (2007). Children in poverty and the use of early development instrument mapping to improve their worlds. Paediatrics and Child Health, 12(8), 687692.

Hertzman, C., \& Boyce, T. (2010). How experience gets under the skin to create gradients in developmental health. Annual Review of Public Health, 31(1), 329-347. http://dx.doi.org/10.1146/annurev.publhealth.012809.103538

Hertzman, C., Power, C., Matthews, S., \& Manor, O. (2001). Using an interactive framework of society and lifecourse to explain self-rated health in early adulthood. Social Science and Medicine, 53(12), 1575-1585. http://dx.doi.org/10.1016/s0277-9536(00)00437-8

Heymann, J., \& McNeill, K. (2013). Children's chances : How countries can move from surviving to thriving. Cambridge, MA: Harvard University Press. http://dx.doi.org/10.4159/harvard.9780674067974

Hochberg, Z., Feil, R., Constancia, M., Fraga, M., Junien, C., Carel, J. C., ... AlbertssonWikland, K. (2011). Child health, developmental plasticity, and epigenetic programming. Endocrine Reviews, 32(2), 159-224. http://dx.doi.org/10.1210/er.2009-0039

Holt-Lunstad, J., Smith, T. B., \& Layton, J. B. (2010). Social relationships and mortality risk: A meta-analytic review. PLoS Med, 7(7), e1000316. http://dx.doi.org/10.1371/journal.pmed.1000316

Jansson, T., \& Powell, T. L. (2007). Role of the placenta in fetal programming: Underlying mechanisms and potential interventional approaches. Clinical Science, 113(1), 1-13. http://dx.doi.org/10.1042/cs20060339 
International Journal of Child, Youth and Family Studies (2015) 6(2): 204-229

Janus, M., Brinkman, S., Duku, E., Hertzman, C., Santos, R., Sayers, M., Schroeder, J., \& Walsh, C. (2007). The Early Development Instrument: Population-based measure for communities. A handbook on development, properties and use. Hamilton, ON: McMaster University.

Jaremka, L. M., Glaser, R., Loving, T. J., Malarkey, W. B., Stowell, J. R., \& Kiecolt-Glaser, J. K. (2013). Attachment anxiety is linked to alterations in cortisol production and cellular immunity. Psychological Science, 24(3), 272-279. http://dx.doi.org/10.1177/0956797612452571

Jenkins, J. M. (2014). Early childhood development as economic development: considerations for state-level policy innovation and experimentation. Economic Development Quarterly, 28(2), 147-165. http://dx.doi.org/10.1177/0891242413513791

Kitzman, H. J., Olds, D. L., Cole, R. E., Hanks, C. A., Anson, E. A., Arcoleo, K. J., ... Holmberg, J. R. (2010). Enduring effects of prenatal and infancy home visiting by nurses on children follow-up of a randomized trial among children at age 12 years. Archives of Pediatrics and Adolescent Medicine, 164(5), 412-418. http://dx.doi.org/10.1001/archpediatrics.2010.76

Kondo, N., Sembajwe, G., Kawachi, I., van Dam, R. M., Subramanian, S. V., \& Yamagata, Z. (2009). Income inequality, mortality, and self rated health: meta-analysis of multilevel studies. British Medical Journal, 339, b4471. doi: 10.1136/bmj.b4471

Kramer, M. S., Goulet, L., Lydon, J., Seguin, L., McNamara, H., Dassa, C., ... Koren, G. (2001). Socio-economic disparities in preterm birth: causal pathways and mechanisms.

Paediatric and Perinatal Epidemiology, 15, 104-123. http://dx.doi.org/10.1046/j.1365-3016.2001.00012.x

Kuh, D., Hardy, R., Langenberg, C., Richards, M., \& Wadsworth, M. E. J. (2002). Mortality in adults aged 26-54 years related to socioeconomic conditions in childhood and adulthood: post war birth cohort study. British Medical Journal, 325(7372), 1076-1080. http://dx.doi.org/10.1136/bmj.325.7372.1076

Lane, M., Robker, R. L., \& Robertson, S. A. (2014). Parenting from before conception. Science, 345(6198), 756-760. http://dx.doi.org/10.1126/science.1254400

Lareau, A. (2011). Unequal childhoods: Class, race, and family life. Berkeley: University of California Press.

Lee, K. (2005). Effects of experimental center-based child care on developmental outcomes of young children living in poverty. Social Service Review, 79(1), 158-180. http://dx.doi.org/10.1086/426721

Lee, K. (2014). Impact of child care arrangements on Australian children's cognitive outcome: moderation effects of parental factors. Child and Family Social Work, doi: 10.1111/cfs.12127.

Leseman, P. (2013). Quality of the early years provisions: European perspectives. Paper presented at the TODDLER Conference, Ghent, Belgium. 
International Journal of Child, Youth and Family Studies (2015) 6(2): 204-229

Love, J. M., Harrison, L., Sagi-Schwartz, A., van, IJzendoorn, M. H., Ross, C., Ungerer, J. A., ... Chazan-Cohen, R. (2003). Child care quality matters: how conclusions may vary with context. Child Development, 74(4), 1021-1033. http://dx.doi.org/10.1111/1467-8624.00584

Luo, Z.-C., Wilkins, R., \& Kramer, M. S. (2006). Effect of neighbourhood income and maternal education on birth outcomes: a population-based study. Canadian Medical Association Journal, 174(10), 1415-1420. http://dx.doi.org/10.1503/cmaj.051096

Marshall, E. (2014). An experiment in zero parenting. Science, 345(6198), 752-754. http://dx.doi.org/10.1126/science.345.6198.752

Maté, G. (2008). In the realm of hungry ghosts: Close encounters with addiction. Toronto: Knopf Canada.

McWilliams, L. A., \& Bailey, S. J. (2010). Associations between adult attachment ratings and health conditions: Evidence from the National Comorbidity Survey Replication. Health Psychology, 29(4), 446. http://dx.doi.org/10.1037/a0020061

Middlebrooks, J., \& Audage, N. (2008). The effects of childhood stress on health across the lifespan. Atlanta: Centers for Disease Control and Prevention, National Center for Injury Prevention and Control.

Miller, G. E., Chen, E., \& Parker, K. J. (2011). Psychological stress in childhood and susceptibility to the chronic diseases of aging: Moving toward a model of behavioral and biological mechanisms. Psychological Bulletin, 137(6), 959-997. http://dx.doi.org/10.1037/a0024768

Montez, J. K., \& Hayward, M. D. (2011). Early life conditions and later life mortality. In R. G. Rogers \& E. M. Crimmins (Eds.), International handbook of adult mortality (pp. 187206). New York: Springer. http://dx.doi.org/10.1007/978-90-481-9996-9_9

National Research Council \& Institute of Medicine. (2013). U.S. Health in international perspective: Shorter lives, poorer health. Washington, DC: The National Academies Press. http://dx.doi.org/10.17226/13497

Nelson, C. A. (2013). Biological embedding of early life adversity. Journal of the American Medical Association Pediatrics, 167(12), 1098-1100. http://dx.doi.org/10.1001/jamapediatrics.2013.3768

Nelson, C. A., Fox, N. A., \& Zeanah, C. H. (2014). Romania's abandoned children. Deprivation, brain development, and the struggle for recovery. Cambridge, MA: Harvard University Press.

Ohlsson, A., Shah, P. S., \& the Knowledge Synthesis Group of Determinants of Preterm/LBW Births. (2011). Effects of the September 11, 2001 disaster on pregnancy outcomes: a systematic review. Acta Obstetricia Et Gynecologica Scandinavica, 90(1), 6-18. http://dx.doi.org/10.1111/j.1600-0412.2010.01020.x 
International Journal of Child, Youth and Family Studies (2015) 6(2): 204-229

Olds, D. L., Kitzman, H. J., Cole, R. E., Hanks, C. A., Arcoleo, K. J., Anson, E. A., ... Stevenson, A. J. (2010). Enduring effects of prenatal and infancy home visiting by nurses on maternal life course and government spending follow-up of a randomized trial among children at age 12 years. Archives of Pediatrics and Adolescent Medicine, 164(5), 419424. http://dx.doi.org/10.1001/archpediatrics.2010.49

Organisation For Economic Co-Operation and Development (OECD). (2007). Babies and bosses - reconciling work and family life: A synthesis of findings for OECD countries. Paris:.Author. http://dx.doi.org/10.1787/9789264032477-en

Osborne, L. A., McHugh, L., Saunders, J., \& Reed, P. (2008). Parenting stress reduces the effectiveness of early teaching interventions for autistic spectrum disorders. Journal of Autism and Developmental Disorders, 38(6), 1092-1103. http://dx.doi.org/10.1007/s10803-007-0497-7

Painter, R. C., Osmond, C., Gluckman, P., Hanson, M., Phillips, D. I. W., \& Roseboom, T. J. (2008). Transgenerational effects of prenatal exposure to the Dutch famine on neonatal adiposity and health in later life. BJOG - an International Journal of Obstetrics and Gynaecology, 115(10), 1243-1249. http://dx.doi.org/10.1111/j.1471-0528.2008.01822.x

Paul, A. M. (2010). Origins: How the nine months before birth shape the rest of our lives. New York: Free Press.

Pesonen, A. K., \& Raikkonen, K. (2012). The lifespan consequences of early life stress. Physiology and Behavior, 106(5), 722-727. http://dx.doi.org/10.1016/j.physbeh.2011.10.030

Piketty, T. (2014). Capital in the twenty-first century (A. Goldhammer, Trans.). Cambridge, MA: Belknap Press of Harvard University Press. http://dx.doi.org/10.4159/9780674369542

Poulton, R., Caspi, A., Milne, B. J., Thomson, W. M., Taylor, A., Sears, M. R., \& Moffitt, T. E. (2002). Association between children's experience of socioeconomic disadvantage and adult health: a life-course study. Lancet, 360(9346), 1640-1645. http://dx.doi.org/10.1016/s0140-6736(02)11602-3

Quan, J., Bureau, J.-F., Yurkowski, K., Moss, E., \& Pallanca, D. (2013). The association between time spent in daycare and preschool attachment to fathers and mothers: An exploration of disorganization. Paper presented at the Conference of the International Journal of Arts and Sciences.

Raphael, D. (2010a). The health of Canada's children. Part III: Public policy and the social determinants of health. Paediatrics and Child Health, 15(3), 143-149.

Raphael, D. (2010b). The health of Canada's children. Part IV: Towards the future. Paediatrics and Child Health, 15(3), 199-204.

Reeves, R. V., \& Howard, K. (2013). The parenting gap. Washington, DC: Center on Children and Families, Brookings Institution. 
International Journal of Child, Youth and Family Studies (2015) 6(2): 204-229

Rilling, J. K., \& Young, L. J. (2014). The biology of mammalian parenting and its effect on offspring social development. Science, 345(6198), 771-776. http://dx.doi.org/10.1126/science.1252723

Runsten, S., Korkeila, K., Koskenvuo, M., Rautava, P., Vainio, O., \& Korkeila, J. (2014). Can social support alleviate inflammation associated with childhood adversities? Nordic Journal of Psychiatry, 68(2), 137-144. http://dx.doi.org/10.3109/08039488.2013.786133

Schore, A. N. (2005). Attachment, affect regulation, and the developing right brain: Linking developmental neuroscience to pediatrics. Pediatrics in Review, 26(6), 204-217. http://dx.doi.org/10.1542/pir.26-6-204

Schreier, H. M. C., \& Chen, E. (2010). Socioeconomic status in one's childhood predicts offspring cardiovascular risk. Brain Behavior and Immunity, 24(8), 1324-1331. http://dx.doi.org/10.1016/j.bbi.2010.06.007

Schulz, L. C. (2010). The Dutch Hunger Winter and the developmental origins of health and disease. Proceedings of the National Academy of Sciences, 107(39), 16757-16758. http://dx.doi.org/10.1073/pnas.1012911107

Seguin, L., Nikiema, B., Gauvin, L., Lambert, M., Tu, M. T., Kakinami, L., \& Paradis, G. (2012). Tracking exposure to child poverty during the first 10 years of life in a Quebec birth cohort. Canadian Journal of Public Health, 103(4), E270-E276.

Stansfeld, S., Head, J., Bartley, M., \& Fonagy, P. (2008). Social position, early deprivation and the development of attachment. Social Psychiatry and Psychiatric Epidemiology, 43(7), 516-526. http://dx.doi.org/10.1007/s00127-008-0330-4

Stansfeld, S. A., Clark, C., Rodgers, B., Caldwell, T., \& Power, C. (2008). Childhood and adulthood socio-economic position and midlife depressive and anxiety disorders. British Journal of Psychiatry, 192(2), 152-153. http://dx.doi.org/10.1192/bjp.bp.107.043208

Suglia, S. F., Enlow, M. B., Kullowatz, A., \& Wright, R. J. (2009). Maternal intimate partner violence and increased asthma incidence in children: Buffering effects of supportive caregiving. Archives of Pediatric Adolescent Medicine, 163(3), 244-250. http://dx.doi.org/10.1001/archpediatrics.2008.555

Tanaka, S. (2005). Parental leave and child health across OECD countries. The Economic Journal, 115(501), F7-F28. http://dx.doi.org/10.1111/j.0013-0133.2005.00970.x

Tobias, M., Kokaua, J., Gerritsen, S., \& Templeton, R. (2010). The health of children in soleparent families in New Zealand: results of a population-based cross-sectional survey. Australian and New Zealand Journal of Public Health, 34(3), 274-280. http://dx.doi.org/10.1111/j.1753-6405.2010.00526.x

Troxel, W. M., \& Matthews, K. A. (2004). What are the costs of marital conflict and dissolution to children's physical health? Clinical Child and Family Psychology Review, 7(1), $29-57$. http://dx.doi.org/10.1023/b:ccfp.0000020191.73542.b0

UNICEF Office of Research - Innocenti. (2013). Innocenti report card No.11, child well-being in rich countries: A comparative overview. Florence: UNICEF. 
International Journal of Child, Youth and Family Studies (2015) 6(2): 204-229

Waylen, A., Stallard, N., \& Stewart-Brown, S. (2008). Parenting and health in mid-childhood: A longitudinal study. European Journal of Public Health, 18(3), 300-305. http://dx.doi.org/10.1093/eurpub/ckm131

Weitoft, G. R., Hjern, A., Haglund, B., \& Rosén, M. (2003). Mortality, severe morbidity, and injury in children living with single parents in Sweden: a population-based study. Lancet, 361(9354), 289-295. http://dx.doi.org/10.1016/s0140-6736(03)12324-0

Wilkinson, R., \& Pickett, K. E. (2010). The spirit level: Why equality is better for everyone. London: Penguin.

Wood-Bradley, R. J., Henry, S. L., Vrselja, A., Newman, V., \& Armitage, J. A. (2013). Maternal dietary intake during pregnancy has longstanding consequences for the health of her offspring. Canadian Journal of Physiological Pharmacology, 91(6), 412-420. http://dx.doi.org/10.1139/cjpp-2012-0352

Wüst, M. (2014). Maternal employment during pregnancy and birth outcomes: Evidence from Danish siblings. Health Economics, doi: 10.1002/hec.3056.

Zahran, S., Breunig, I. M., Link, B. G., Snodgrass, J. G., Weiler, S., \& Mielke, H. W. (2014). Maternal exposure to hurricane destruction and fetal mortality. Journal of Epidemiology and Community Health, 68(8), 760-766. http://dx.doi.org/10.1136/jech-2014-203807

Zeltser, L. M., \& Leibel, R. L. (2011). Roles of the placenta in fetal brain development. Proceedings of the National Academy of Sciences, 108(38), 15667-15668. http://dx.doi.org/10.1073/pnas.1112239108 